\title{
PENGARUH IMPLEMENTASI KEBIJAKAN SERTIFIKASI GURU, KOMPETENSI GURU TERHADAP KINERJA GURU DI MTS AL-MUQOWAMAH SINGAPARNA TASIKMALAYA
}

\author{
Neneng Arni Nuraeni \\ Program Magister Ilmu Administrasi Negara Konsentrasi Administrasi Kebijakan Pendidikan \\ Sekolah Tinggi Ilmu Administrasi YPPT Tasikmalaya \\ J1. Perintis Kemerdekaan No. 200, Karsamenak, Kec. Kawalu, Tasikmalaya, Jawa Barat 46182 \\ Email: arni_nuraeni@ymail.com \\ Idrus Affandi \\ Universitas Pendidikan Indonesia \\ Jl. Dr. Setiabudhi No. 229 Bandung 40154 Jawa Barat - Indonesia \\ Ani Heryani \\ Sekolah Tinggi Ilmu Administrasi YPPT Tasikmalaya \\ J1. Perintis Kemerdekaan No. 200, Karsamenak, Kec. Kawalu, Tasikmalaya, Jawa Barat 46182
}

\begin{abstract}
Abstrak
Sumber daya manusia (human resources) merupakan aset pokok yang diperlukan untuk mencapai keberhasilan pembangunan. Guru sebagai sumber daya manusia mempunyai kedudukan sebagai tenaga profesional pada jenjang pendidikan dasar, pendidikan, menengah, dan pendidikan anak usia dini pada jalur pendidikan formal yang diangkat sesuai dengan peraturan perundangundangan. Pengakuan kedudukan guru sebagai tenaga profesional tersebut dibuktikan dengan sertifikat pendidik. Tujuan penelitian ini adalah untuk mengetahui impementasi kebijakan sertifikasi guru, kinerja guru, pengaruh implementasi kebijakan sertifikasi guru terhadap kinerja guru dan mengetahui pengaruh kompetensi guru terhadap kinerja guru di MTs Al-Muqowamah Tasikmalaya. Metode yang digunakan dalam penelitian ini yaitu metode penelitian kuantitatif dengan pendekatan cross sectional yaitu penelitian yang bertujuan untuk menguji pengaruh antar variabel yang dihipotesiskan dan karena jumlah populasinya relatif sedikit, maka semua polulasi dijadikan sebagai responden yaitu sebanyak 34 orang guru di MTs Al -Muqowamah Kabupaten Tasikmalaya, serta alat analisis yang digunakan adalah alat analisis jalur path. Hasil penelitian melalui uji t (regresi parsial) menunjukan bahwa impelementasi kebijakan dan kompetensi guru berpengaruh positif secara parsial terhadap kinerja guru. Variabel implementasi kebijakan memiliki koefesiensi sebesar 0,592. Adapun pengaruh langsung dan tidak langsung sebesar 50. 1\%. sedangkan Variabel kompetensi guru (x2) mempunyai koefesiensi jalur 0,419. Adapun pengaruh langsung dan tidak langsung sebesar 32. 6\%. Oleh karena itu perlu ditekankan bahwa sosialisasi kebijakan sertifikasi guru perlu dikembangkan dan konsisten sehingga guru dapat melakukan proses sertifikasi, mengikuti pelatihan yang lebih bermutu maupun usaha belajar secara mandiri untuk mencapai peningkatan profesionalisme untuk meningkatkan kinerja guru.
\end{abstract}

Kata Kunci:

Implementasi Kebijakan sertifikasi guru, kompetensi, kinerja guru

\begin{abstract}
Human resources (human resources) are the main assets needed to achieve successful development. Teachers as human resources have a position as professionals at the level of basic education, education, secondary, and early childhood education in the formal education pathways that are appointed in accordance with statutory regulations. Recognition of the position of the teacher as a professional is proven by an educator certificate. The purpose of this study was to determine the implementation of teacher certification policies, teacher performance, the effect of the implementation of teacher certification policies on teacher performance and determine the effect of teacher competence on teacher performance in Al-Muqowamah Tasikmalaya MTs. The method used in this study is a quantitative research method with a cross sectional approach that is research that aims to examine the influence between hypothesized variables and because the population is relatively small, all polls are used as respondents, as many as 34 teachers in MTs Al-Muqowamah Tasikmalaya Regency, and the analysis tool used is the path analysis tool. The results of the study through the t test (partial regression) showed that the implementation of policies and teacher competencies had a partially positive effect on teacher performance. The policy implementation variable has a coefficient of 0.592 . The direct and indirect effects of 50.1\%. while the Teacher competency variable (x2) has a path coefficient of 0.419 . The direct and indirect effects of $32.6 \%$. Therefore it needs to be emphasized that the socialization of teacher certification policies needs to be developed and consistent so that teachers can carry out the certification process, attend higher quality training and independent learning efforts to achieve increased professionalism to improve teacher performance.
\end{abstract}

Keywords:

Implementation of teacher certification policies, competencies, teacher performance 


\section{A. PENDAHULUAN}

Sumber daya manusia (human resources) merupakan aset pokok yang diperlukan untuk mencapai keberhasilan pembangunan suatu bangsa. Sebagai penggerak pembangunan, sumberdaya manusia dituntut untuk mampu mengatasi segala tantangan dan harapan mampu memanfaatkan peluang serta dapat memenuhi tuntutan kebutuhan lingkungan kerjanya. Dengan demikian, sumberdaya manusia tidak hentihentinya ditantang untuk lebih mampu mengembangkan potensi yang ada, ditambah upaya lain dalam kaitannya dengan peningkatan kualitas kemampuan dan sekaligus mendukung produktivitas.

Kebutuhan akan keluaran (manusia berkualitas) terasa semakin meningkat dalam era globalisasi sekarang ini, karena era termaksud merupakan era yang menuntut peran serta sumberdaya manusia yang memiliki kemampuan yang profesional sebagai pelaksana pembangunan. Hal tersebut mengisyaratkan bahwa pendidikan dengan berbagai programnya mempunyai peranan penting dalam proses memperoleh dan meningkatkan kualitas kemampuan profesional dalam melaksanakan pembangunan, karena hal ini sangat dibutuhkan sebagai aset pembangunan nasional.

Rendahnya kualitas sumber daya manusia merupakan masalah mendasar yang dapat menghambat pembangunan dan perkembangan ekonomi sosial. Penataan sumber daya manusia perlu diupayakan secara bertahap dan berkesinambungan melalui sistem pendidikan yang berkualita baik pada jalur pendidikan formal, informal maupun non formal, mulai dari pendidikan dasar sampai perguruan tinggi.

Pengembangan sistem pendidikan yang berkualitas perlu lebih ditekankan, karena berbagai indikator menunjukan bahwa pendidikan yang ada belum mampu menghasilkan sumber daya manusia sesuai dengan perkembangan masyarakat dan kebutuhan pembangunan.

Pendidikan merupakan salah satu cara yang tepat untuk mendapatkan mutu sumber daya manusia yang sesuai dengan tuntutan kebutuhan pembangunan. Melalui proses pendidikan sumber daya manusia dapat berkembang terutama dalam aspek kemampuan intelektual dan kepribadian. Pendidikan pada umumnya diartikan dan bertujuan memanusiakan manusia. Pendidikan juga dianggap sebagai suatu variabel modernisasi atau pembangunan, karena tanpa pendidikan yang memadai akan sulit bagi masyarakat manapun untuk mencapai kemajuan. Karena itu banyak para ahli pendidikan yang berpendapat bahwa pendidikan merupakan kunci ke arah modernisasi.

Sebagai upaya percepatan peningkatan mutu pendidikan dalam rangka menyongsong era globalisasi, pemerintah telah berhasil menyusun Undang Undang No. 20 tahun 2003 tentang sistem pendidikan Nasional, yang selanjutnya secara operasional sudah dijabarkan ke dalam beberapa peraturan pemerintah, dan salah satunya dalam PP 19 tahun 2005 yaitu Standar Nasional Pendidikan nasional yang dimaksudkan dalam upaya meningkatkan kualitas pendidikan nasional.

Kualitas pendidikan dan lulusan seringkali dipandang tergantung kepada peran guru dalam mengelola komponen-komponen pengajaran yang digunakan dalam proses belajar mengajar yang menjadi tanggung jawabnya. Seperti yang dijelaskan oleh Mulyasa (2008, hal: 8): "untuk merekayasa sumber daya manusia yang berkualitas diperlukan guru yang profesional yang merupakan penentu keberhasilan pendidikan".

Guru mempunyai kedudukan sebagai tenaga profesional pada jenjang pendidikan dasar, pendidikan, menengah, dan pendidikan anak usia dini pada jalur pendidikan formal yang diangkat sesuai dengan peraturan perundang-undangan. Pengakuan kedudukan guru sebagai tenaga profesional tersebut dibuktikan dengan sertifikat pendidik. Lebih lanjut Undang-Undang Nomor 14 Tahun 2005 tentang Guru tersebut mendefinisikan bahwa profesional adalah pekerjaan atau kegiatan yang dilakukan oleh seseorang dan menjadi sumber penghasilan kehidupan yang memerlukan keahlian, kemahiran, atau kecakapan yang memenuhi standar mutu atau norma tertentu serta memerlukan pendidikan profesi.

Undang-Undang Nomor 14 tahun 2005 Tentang Guru dan Dosen menyatakan bahwa guru adalah pendidik profesional dengan tugas utama mendidik, mengajar, membimbing, mengarahkan, melatih, menilai, dan mengevaluasi peserta didik pada pendidikan anak usia dini jalur pendidikan formal, pendidikan dasar, dan pendidikan menengah. Seorang guru harus memiliki kompetensi sebagai agen pembelajaran yang meliputi kompetensi pedagogik, kompetensi kepribadian, kompetensi profesional, dan 
kompetensi sosial. Keempat kompetensi tersebut tercermin secara integratif dalam kinerja guru dan dibuktikan dengan sertifikat pendidik yang diperoleh melalui uji kompetensi.

Kenyataan dilapangan didapatkan fenomena bahwa MTs Al-Muqowamah merupakan salah satu sekolah swasta dibawah Yayasan Al Muqowamah. Dimana yayasan tersebut merupakan Yayasan Pendidikan yang tidak memiliki badan usaha bersifat komersial. Hal ini akan berdampak pada kebijakan internal dalam pemberian kesejahteraan bagi guru honorer dan guru lain yang berjumlah 34 orang. Menurut data yang diperoleh dari MTs Al Muqowamah didapatkan dari jumlah 34 orang guru yang bertugas, sebanyak 3 orang diantaranya berstatus PNS sekaligus sudah mendapatkan sertifikasi, sebanyak 9 orang lainnya sudah mendapat sertifikasi sehingga 22 orang honorer yang menjadi kewajiban yayasan untuk memberikan gaji atau kesejahteraan, namun dari guru honorer tersebut sudah ada yang mendapatkan tunjangan fungsional.

\section{Implementasi Kebijakan}

Implementasi merupakan tahap yang sangat menentukan di dalam proses kebijakan, karena tanpa implementasi yang efektif maka keputusan pembuat kebijakan tidak akan berhasil dilaksanakan. Keberhasilan kebijakan publik bukan karena isinya saja yang membuat berhasil diterapkan, peran para pelaksana atau implementor kebijakan publik juga sangat berpengaruh. Sejalan dengan, Chief J. O. Udoji (Agustino, 2008, hal: 140) yang mengatakan bahwa implementasi kebijakan adalah sesuatu yang penting dan bahkan jauh lebih penting daripada pembuatan kebijakan. Kebijakankebijakan hanya sekedar berupa impian atau rencana bagus yang tersimpan rapi dalam arsip kalau tidak diimplementasikan.

\section{Sertifikasi Guru}

Dalam undang undang Republik indonesia no 14 tahun 2005 tentang guru dan dosen,dikemukakan bahwa sertifikasi adalah proses pemberian sertifikat pendidik untuk guru dan dosen. Sedangkan sertifikat pendidik adalah bukti formal sebagai pengakuan yang diberikan kepada guru dan dosen sebagai tenaga profesional. Berdasarkan pengertian tersebut sertifikat guru dapat diartikan sebagai suatu proses pemberian pengakuan bahwa seseorang telah memiliki kompetensi untuk melaksanakan pelayan pendidikan pada satuan pendidikan tertentu, setelah lulus uji kompetensi yang diselenggarakan oleh lembaga sertifikasi . dengan kata lain sertifikasi guru adalah proses uji kompetensi yang dirancang untuk mengungkapkan penguasaan kompetensi seorang guru sebagai landasan pemberian sertifikat pendidik (E. Mulyasa, 2007, hal: 33 - 34).

\section{Kebijakan Sertifikasi Guru}

Sertifikasi merupakan pengakuan secara formal akan profesi sebagai seorang guru yang profesional bahwa guru tersebut secara formal telah mempunyai kompetensi dalam bidang studi yang diembannya. Dasar utama pelaksanaan sertifikasi guru adalah Undang- Undang nomor 14 tahun 2005 tentang Guru dan Dosen (UUGD) yang disahkan tanggal 30 Desember 2005. Pasal yang menyatakannya secara yuridis menurut ketentuan menurut ketentuan pasal 1 ayat (11) UUGD adalah pemberian sertifikat pendidik untuk guru dan dosen.

\section{Faktor yang mempengaruhi kebijakan publik}

Menurut George Edward III dalam bukunya "Implementing Public Policy" terdapat 4 variabel yang dapat mempengaruhi implementasi kebijakan publik: Komunikasi, Sumber Daya, Disposisi (Kepribadian) dan Struktur Birokrasi.

\section{Kompetensi Guru}

Wibowo (2007, hal: 86) menyatakan kompetensi adalah: "Kemampuan untuk melaksanakan atau melakukan suatu pekerjaan atau tugas yang dilandasi atas keterampilan dan pengetahuan serta didukung oleh sikap kerja yang dituntut oleh pekerjaan tersebut".

\section{Dimensi Kompetensi}

Mitrani dan Dalziel (1994, hal: 27) mengemukakan unsur-unsur atau komponen kompetensi sebagai berikut:

A competency is defined as underlying characteristic of individual which is casually related to effective or superior performance in a job. Competencies can be motives, self concept, attitudes or values, concept knowledge behavioral skills.

Sifat-sifat dasar di atas dapat dijelaskan bahwa dalam kompetensi terdapat unsur-unsur atau komponen sebagai berikut: 
1. Motif, Sikap, Watak, Self concept, Pengetahuan, Kemampuan kognitif yang dimiliki oleh individu pegawai, Keahlian perilaku dan kesadaran: yaitu keterampilan yang dimiliki oleh pegawai yang secara sadar digunakan untuk menyelesaikan pekerjaannya.

Mengacu pada Permendiknas Nomor 16 tahun 2007 Mengenai standar kompetensi guru dijelaskan sebagai berikut: Kompetensi Pedagogik, Kompetensi Kepribadian, Kompetensi sosial dan Kompetensi sosial

\section{Kinerja Guru}

Kinerja guru merupakan seperangkat perilaku nyata yang ditunjukkan guru pada waktu memberikan pelajaran pada siswanya. Oleh karenanya untuk menilai kinerja guru dapat dilakukan dengan cara mencermati pelaksanaan kompetensi yang dimiliki oleh guru yang bersangkutan meliputi mendidik, mengajar, membimbing, mengarahkan anak, melatih, melakukan penilaian dan mengevaluasi.

\section{Aspek-Aspek Kinerja Guru}

Kinerja adalah hasil kerja dalam mencapai suatu tujuan atau persyaratan pekerjaan yang telah ditetapkan. Kinerja guru dapat dilihat pada beberapa aspek berikut: Mendidik, Mengajar, Membimbing, Mengarahkan, Melatih, Menilai dan Mengevaluasi Keberhasilan sekolah ditentukan oleh banyak faktor, salah satu faktor diantaranya adalah kinerja guru.

Kinerja guru merupakan faktor yang paling menentukan kualitas pembelajaran. Dengan demikian, peningkatan mutu pendidikan kualitas kinerja guru perlu mendapat perhatian utama dalam penetapan kebijakan. Kinerja guru sebagai seperangkat perilaku nyata yang ditunjukkan guru pada waktu dia memberikan pelajaran kepada siswanya.

Kinerja guru merupakan seperangkat perilaku nyata yang ditunjukkan guru pada waktu ia memberikan pelajaran pada siswanya. Oleh karenanya untuk menilai kinerja guru dapat dilakukan dengan cara mencermati pelaksanaan kompetensi yang dimiliki oleh guru yang bersangkutan yakni Mendidik, Mengajar, Membimbing, Mengarahkan, Melatih, Menilai, Mengevaluasi

Salah satu terobosan yang sedang dilakukan dalam meningkatkan kinerja guru adalah dengan melakukan sertifikasi guru. Kebijakan sertifikasi guru yang telah diimplementasikan selama lima tahun pertama melalui pola penilaian portofolio dan lainnya sebagai langkah yang strategis untuk dapat meningkatkan mutu pendidikan. Kebijakan pemerintah mengenai pelaksanaan sertifikasi guru muncul dari tuntutan penciptaan sosok guru yang profesional. Profesionalitas seorang guru di atas kertas dibuktikan dengan sertifikat pendidik. Dan sebagai tenaga profesional, guru dipersyaratkan memiliki kualifikasi akademik S-1 (strata satu) atau D4 (diploma empat) dalam bidang yang relevan dengan mata pelajaran yang diampunya dan menguasai kompetensi sebagai agen pembelajaran.

Memahami implementasi kebijakan sertifikasi guru sangatlah krusial dan kompleks dalam perspektif administrasi publik dan kebijakan publik, hal ini berkaitan dengan aspek kebijakan itu sendiri yang tidak terlepas hubungannya dengan berbagai kelembagaan dalam suatu sistem pendidikan sebagaimana halnya dalam implementasi kebijakan sertifikasi guru banyak melibatkan unsur koordinasi antar departemen pada tingkat pusat yang cukup birokratis dan overlapping maupun kompleksitas dalam implementasi operasional pada tingkat pemerintahan daerah khususnya pada pemerintahan kota atau kabupaten dan aspek masyarakat dalam hal ini guru sebagai objek kebijakan.

Berdasarkan kerangka pemikiran di atas maka dapat dirumuskan hipotesis penelitian yaitu:

1. Terdapat pengaruh yang signifikan antara kebijakan sertifikasi guru terhadap kinerja guru di MTs Al-Muqowamah.

2. Terdapat pengaruh yang signifikan antara kompetensi guru terhadap kinerja guru di MTs Al Muqowamah

Objek penelitian merupakan permasalahan yang diteliti. Menurut Sugiyono (2010) menyebutkan objek penelitian (variabel penelitian) adalah karakteristik tertentu yang mempunyai nilai, skor atau ukuran yang berbeda untuk unit atau individu yang berbeda atau merupakan konsep yang diberi lebih dari satu nilai. Objek dari penelitian ini adalah implementasi kebijakan sertifikasi guru, kompetensi dan kinerja guru di MTS Al Muqowamah Tasikmalaya. Metode yang digunakan dalam penelitian ini adalah metode deskriptif kuantitatif. yaitu suatu bentuk penelitian 
yang bertujuan menggambarkan serta menganalisis keadaan yang sebenarnya dimana data yang digunakan berupa angka dan perhitungan-perhitungan, berdasarkan pendekatan, penelitian ini menggunakan desain cross sectional, dimana penelitian hanya dilakukan

\section{Hasil uji pengaruh implementasi kebijakan, kompetensi terhadap kinerja guru}

a. Hasil analisis korelasi sekali saja tanpa ada perulangan dalam pengambilan data.

\section{B. HASIL DAN PEMBAHASAN}

Tabel 1. Matrik Korelasi Antara Variabel

\begin{tabular}{|c|c|c|c|}
\hline Variabel & $\mathbf{X 1}$ & $\mathbf{X 2}$ & $\mathbf{Y}$ \\
\hline $\mathrm{X} 1$ & 1 & $.606^{* *}$ & $.846^{* *}$ \\
\hline $\mathrm{X} 2$ & $.606^{* *}$ & 1 & $.777^{* *}$ \\
\hline $\mathrm{Y}$ & $.846^{* *}$ & $.777^{* *}$ & 1 \\
\hline
\end{tabular}

Sumber: hasil pengolahan data melalui SPSS. 17.00

b. Hasil Pengujian jalur

Berdasarkan hasil pengujian jalur (path) melalui program software SPSS 20. 0 dapat dilihat sebagai berikut:

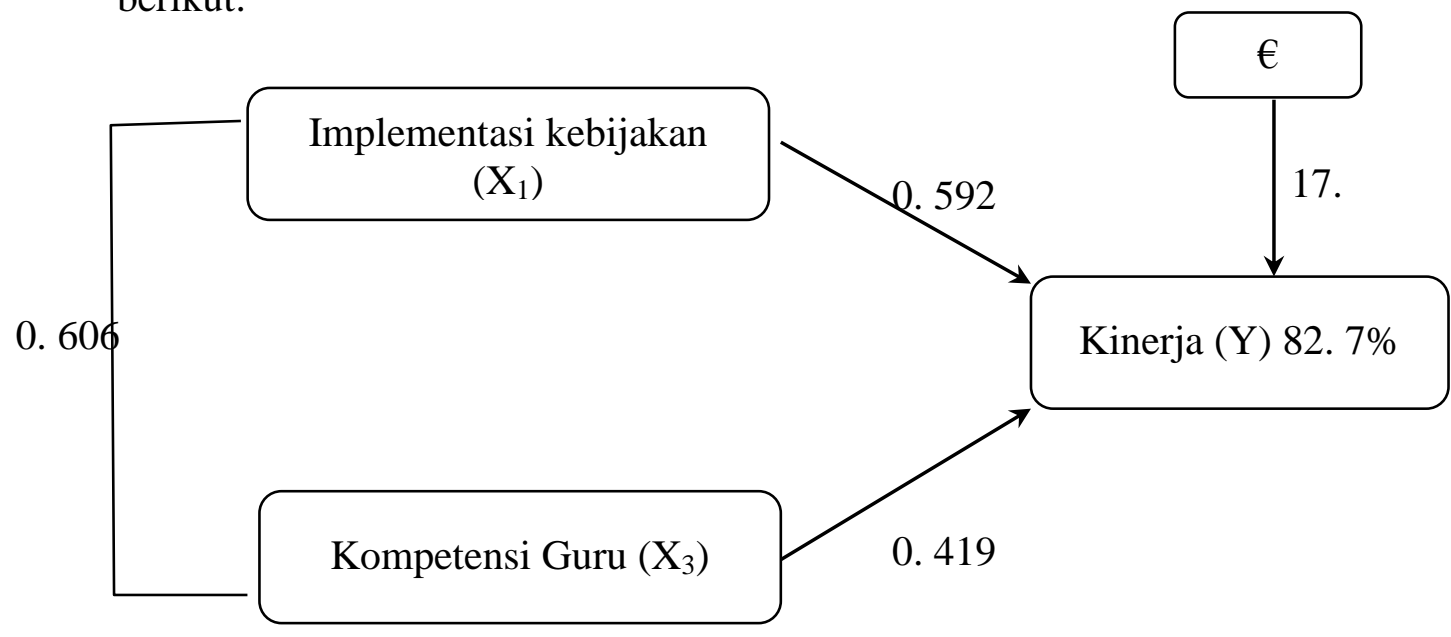

Gambar 1. Hasil Jalur Pengujian Jalur

Pada gambar diatas dari hasil uji korelasi menunjukkan bahwa semua variabel tersebut berkorelasi secara signifikan dengan koefisien seperti tabel dibawah ini. Data pada tabel diatas menunjukkan hasil perhitungan jalur, bahwa variabel implementasi kebijakan (x1) mempunyai koefisien jalur 0,592, variabel kompetensi guru (x2) mempunyai koefisien jalur 0,419. Berdasarkan perhitungan yang terlihat pada hasil analisis jalur, maka dapat diukur besarnya pengaruh langsung dan tidak langsung antara implementasi kebijakan (x1), kompetensi guru (x2) terhadap kinerja guru (Y). hasil pengukuran tersebut disajikan dalam tabel berikut:

Tabel 2. Koefisien jalur pada variabel disiplin kerja

\begin{tabular}{|c|c|}
\hline Variabel & Koefisien jalur terhadap Y \\
\hline Implementasi kebijakan (x1) & 0,592 \\
\hline Kompetensi guru (x2) & 0.419 \\
\hline
\end{tabular}




\section{Pembahasan}

\section{a. Implementasi Kebijakan sertifikasi guru di MTs Al-Muqowamah Kabupaten} Tasikmalaya

Berdasarkan dari hasil penelitian ini didapatkan bahwa Implementasi kebijakan sertifikasi guru di MTs Al-Muqowamah Tasikmalaya termasuk tinggi dengan skor tertinggi sebesar 153 point. Melihat dari hal tersebut mengindikasikan bahwa persepsi terhadap implementasi kebijakan sertifikasi guru telah sesuai dengan harapan yang diinginkan oleh responden.

Sertifikasi ini sebagai bukti formal sebagai pengakuan yang diberikan kepada guru dan dosen sebagai tenaga profesional. Berdasarkan pengertian tersebut sertifikat guru dapat diartikan sebagai suatu proses pemberian pengakuan bahwa seseorang telah memiliki kompetensi untuk melaksanakan pelayan pendidikan pada satuan pendidikan tertentu, setelah lulus uji kompetensi yang diselenggarakan oleh lembaga sertifikasi . dengan kata lain sertifikasi guru adalah proses uji kompetensi yang dirancang untuk mengungkapkan penguasaan kompetensi seorang guru sebagai landasan pemberian sertifikat pendidik

\section{b. Kompetensi Guru di MTs Al-Muqowamah Kabupaten Tasikmalaya}

Hasil penelitian ini didapatkan bahwa kompetensi guru sudah termasuk baik, dimana nilai tertinggi sebesar 151 point. Hal ini mengindikasikan bahwa responden telah memiliki dimensi-dimensi kompetensi seperti pengetahuan, keterampilan, profesionalisme, sosial dan lainnya

\section{c. Kinerja Guru di MTs Al-Muqowamah Kabupaten Tasikmalaya}

Hasil penelitian ini didapatkan bahwa kinerja guru termasuk kategori tinggi, dimana nilai terbesar adalah 151 point, hal ini mengindikasikan bahwa kinerja guru yang sesuai dengan prosedur dan tugas serta perannya sebagai guru.

Menurut analisis peneliti kinerja guru tersebut dipandang sebagai seperangkat perilaku nyata yang ditunjukkan guru pada waktu dia memberikan pelajaran kepada siswanya. Kinerja guru merupakan seperangkat perilaku nyata yang ditunjukkan guru pada waktu ia memberikan pelajaran pada siswanya.

\section{SIMPULAN}

Sesuai dengan penelitian yang telah dilakukan dan pembahasannya mengenai pengaruh implementasi kebijakan dan kompetensi guru terhadap kinerja guru MTs Al-Muqowamah Kabupaten Tasikmalaya, penulis memperoleh kesimpulan sebagai berikut:

1. Implementasi kebijakan sertifikasi guru di MTs Al-Muqowamah Tasikmalaya termasuk tinggi dengan skor tertinggi sebesar 153 point.

2. Kompetensi guru di MTs Al-Muqowamah Tasikmalaya termasuk tinggi dengan skor tertinggi sebesar 151 point

3. Kinerja guru di MTs Al-Muqowamah Tasikmalaya termasuk tinggi dengan skor tertinggi sebesar 151 point.

4. Terdapat pengaruh implementasi kebijakan sertifikasi guru terhadap kinerja guru di MTs Al-Muqowamah Tasikmalaya, analisis jalur path variabel implementasi kebijakan memiliki koefisien sebesar 0,592. Adapun pengaruh langsung dan tidak langsung sebesar $50.1 \%$

5. Terdapat pengaruh kompetensi guru terhadap kinerja guru di MTs Al-Muqowamah Tasikmalaya dimana variabel kompetensi guru (x2) mempunyai koefisien jalur 0,419. Adapun pengaruh langsung dan tidak langsung sebesar 32. 6\%.

Adapun saran berdasarkan penelitian yang dilaksanakan dengan mengetahui adanya pengaruh yang positif antara lain:

1. Implementasi kebijakan dalam penelitian ini sudah baik, namun perlu ditekankan bahwa sosialisasi kebijakan sertifikasi guru perlu dikembangkan dan konsisten sehingga guru dapat melakukan proses sertifikasi seperti sosialisasi pelaksanaan sertifikasi guru.

2. Untuk meningkatkan kompetensi guru, maka guru sebaiknya perlu mengikuti pelatihan yang lebih bermutu maupun usaha belajar secara mandiri untuk mencapai peningkatan profesionalisme.

3. Kinerja guru MTs Al-Muqowamah berada pada kategori cukup baik. Perlu diperhatikan hal-hal yang memberikan kontribusi terhadap peningkatan kinerja guru. 


\section{DAFTAR PUSTAKA}

Agustino, Leo. 2008. Dasar-Dasar Kebijakan Publik. Bandung: Alfabeta/

Arikunto, Suharsimi, 2013. Prosedur Penelitian

Suatu Pendekatan Praktek. Jakarta. PT. Rineka Cipta.

Armstrong and Baron (1996P) Social Psychology: Understanding Human Interaction. Boston: Allyn and Bacon

Atmodiwiryo, 2002. Soebagio, Manajemen Pendidikan Indonesia, Jakarta: Arda Dizya

Bernardin, H. John and Russel. 1998. Human Resource Management. New York: McGraw-Hill

Blau, Gary. 2000. Testing The Longitudinal Impact of Work Variables and performance Appraisal Satisfaction on Subsequent Overall Job Satisfaction. Human Relation. New York

Boynton, Willian C. , Raymond N. Johnson. 2006. Modern Auditing. Edisi 8. USA: Wiley

Cece Wijaya (2000, hal: 7) Konsep dan Implementasi Kurikulum 2004, Bandung: PT Remaja Kemampuan Dasar Guru Dalam Proses Belajar Mengajar. Bandung: Rosdakarya

Dalziel M, dan Hill J (1996). People and Competencies, Bidlles

Departemen Pendidikan (1992). Peraturan Pemerintah Republik Indonesia Nomor 29 Tahun 1990 tentang Pendidikan Menengah. Jakarta: Kemendikna

Desler (2003). Manajemen Sumber Daya Manusia. Jakarta: Salemba. Empat.

Dharma (2005). Manajemen Kinerja. Yogyakarta: Pustaka Pelajar

George Edward III 1998. "Implementing Public Policy" Everett M. Rogers

Gima Sugiama. 2011. Metode Riset Bisnis dan Manajemen, Bandung: Guardaya Intimarta.

Gulo, Dali. (2006). Kamus Psikologi. Bandung: Pionir Jaya

Hendry. (2010). Aplikasi Analisis Jalur Dengan SPSS Versi 15. 0. http: //teorionline. wordpress. com/2010/ 03/11/aplikasianalisis-jalur-dengan-spssversi-15-0/.

(Diakses Tanggal 13 September 2019)

Indiahono, Dwiyanto. 2009. Kebijakan Publik Berbasis Dynamic Policy Analysis. Yogyakarta: Gava Media
Isjoni. 2010. Cooperative Learning Efektifitas Pembelajaran Kelompok. Alfabeta. Bandung

Ivancevic dan Donelly (1997). Organisasi, perilaku dan proses. Bina Rupa Aksara

Katz dan Rosenweigh (2001) Organisasi Dan Manajemen, Jakarta: Bumi. Aksara

Knowledge Management dalam Konteks Organisasi Pembelajar. Bandung: SBM ITB

Kunandar. 2011. Penilaian Autentik. Rajawali Pers. Jakarta

Kusumanegara, Solahuddin. 2010. Model dan Aktor dalam Proses Kebijakan Publik. Yogyakarta: Gava Media

Lucio, W. H. \& McNeil, J. D. (1979). Supervision in thought and action. New York: McGrawHill

Maarif (2003). Pendidikan Agama Islam Berbasis Kompetensi. :

Moekijat. (2012). Pengembangan Manajemen dan Motivasi. Bandung: Pionir Jaya

Mulyasa, E. 2008. Standar Kompetensi dan Sertifikasi Guru. Bandung: PT Remaja Rosdakarya

Nasution, M. N. (1992). Manajemen Mutu Terpadu: Total Quality Management, Edisi Kedua, Ghalia Indonesia, Bogo

Natawijaya, Rohman. 1999. Psikologi Pendidikan. Jakarta: Prindo Jaya

Nawawi, Hadari, (2005), Manajemen Sumber Daya Manusia, Yogyakarta: Gajah Mada University Press

Noe, R. A., Hollenbeck, J. R. , Gerhart, B. and Wright, P. M. (2006). Human Resource Management: Gaining a competitive advantage, New York: McGraw Hill

Nugroho. 2003. Kebijakan Publik, Formulasi, Implementasi dan Evaluasi. Jakarta: Elex Media Komputindo

Robert Houston, 2005, Handbook of Research on Teacher Education, MacMillan Publishing Company, London 